\title{
The Effect of Financial Crisis in Corporate
}

\section{Social Responsibility Performance}

\author{
Grigoris Giannarakis (Corresponding author) \\ University of the Aegean, Department of Shipping Trade and Transport \\ Korai 2A, 82100, Chios, Greece \\ Tel: 30-227-103-5200Ｅ-mail: ggianaris@aegean.gr \\ Ioannis Theotokas (Assistant Professor) \\ University of the Aegean, Department of Shipping Trade and Transport \\ Korai 2A, 82100, Chios, Greece \\ Tel: 30-227-103-5203 E-mail: gtheotokas@aegean.gr
}

\begin{abstract}
The aim of the study is to evaluate the effect of financial crisis in Corporate Social Responsibility (CSR) performance. An empirical analysis is conducted, based on companies that implement Global Report Initiatives (GRI) reporting guidelines modifying the application level in a point score system. Totally, 112 companies are included in the GRI report list in 2007, pre-financial crisis, 2008, 2009 and 2010. The Wilcoxon signed rank sum test is used in order to ascertain whether an economic downturn affects CSR performance. Results indicate increased CSR performance before and during the financial crisis except for the period 2009-2010. Companies increase their performance in order to regain the lost trust in businesses. The study also promotes a discussion with regards to a financial crisis and CSR performance and reporting.
\end{abstract}

Keywords: Corporate Social Responsibility, Report, Global Reporting Initiative, Performance, Report

\section{Introduction}

Corporate Social Responsibility (CSR) has received increased attention from numerous authors and international organizational bodies. Various definitions have been developed in order to specify the role of business in the society. There is no consensus as regards the term «society» (Maignan et al., 2005), thus, the concept of stakeholders personalizes social responsibilities by delineating the specific groups that a business should consider in its orientation. The Commission of the European Communities (2001) defines CSR as "a concept whereby companies integrate social and environmental concerns in their business operations...on a voluntary basis". Palazzi and Starcher (2000) support that CSR is elaborated in its unique way depending on the stakeholder expectations. Kitchin (2002) mentions that CSR meaning is changing over time while Lantos (2001) supports that it is a useful marketing tool. It can ensure a long term value and gain competitive advantages mitigating a new type of risk that has emerged, known as social risk (Kytle and Ruggie, 2005).

The starting point of the financial crisis is placed at 2007 in the USA because of the liquidity shortfall in the banking system (Taylor and Williams, 2009). However, the financial results in Europe and USA were more severe in 2008 (European Commission 2009; Aizenman et al., 2010) especially in the second quarter (Wyplosz, 2010). The European countries were affected by the current crisis due to their exposure to the USA financial markets (Wim, 2009). The majority of EU and USA companies confronted difficulties in an attempt to borrow financial capitals form the banks (Njoroge, 2009) restricting operational and investment procedures. As regards the Asian-Pacific region, the impact of the financial downturn in 2007 was limited, while the third quarter of 2007 until the first quarter of 2009 is considered the sharpest period of the current crisis (Filardo et al., 2010). Some of the severe consequences of financial downturn are stock indexes fall, financial institutions collapse, higher unemployment, poverty and governments needs rescue financial packages to bail out their financial systems (Adamu, 2009; Wim, 2009). Companies are compelled by financial circumstances to restrict their expenses including reneging on their corporate social responsibilities as it generates costs (Orlitzky et al., 2003; Fernández and Souto, 2009). Njoroge (2009) concludes that CSR initiatives can be delayed or cancelled because of the financial crisis. However, the global financial crisis provides great opportunities for companies such as corporate brands, employees' satisfaction, economic performance and increased productivity. 
The aim of the study is whether CSR performance has changed in periods before and during the financial crisis. The evaluation of CSR performance is based on annual corporate reports where the application level of GRI guidelines is modified in CSR performance. The annual report is considered as a methodological tool measuring CSR performance (Hino, 2006; Karaibrahimoglu, 2010; Turker, 2009). The subjective evaluation of CSR reports can be overcome by using internationally accepted CSR reporting guidelines. GRI is used in order to bypass subjective evaluation process and classifies companies according to the application level of reporting guidelines.

This study has the following structure: In section 2, there is a presentation of literature review of previous studies concerning the relationship between CSR and financial crisis. Section 3 describes CSR performance tools. Section 4 examines methodology of the research. Section 5 provides the analysis of results while in the last part, section 6 , the conclusion is presented.

\section{Financial Crisis and Corporate Social Responsibility}

The international literature on interaction between financial crisis and CSR is scarce. Fernández and Souto (2009) investigate the consequences of the latest economic and financial crisis on CSR. Both managers and stockholders are affected by the economic recession. It is noted that there is no consensus as regards the relationship between CSR and business economic performance. CSR is concerned to be a threat for companies' survival because of the additional financial cost for the social initiatives. As CSR is not temporary and there is no widely accepted CSR framework, seven common issues are recommended for CSR implementation in period of crisis: innovation, comfortable atmosphere, stakeholders' role, business strategy, market attitude, investor confidence and deep internal reflection. The most important negative impact of CSR to companies is the potential cost for the implementation of CSR initiatives. Companies need to change or redefine their business objectives in relation to social expectations (Porter and Kramer, 2002; Fernández and Souto, 2009).

Karaibrahimoglu (2010) investigates CSR performance for the period 2007, pre financial crisis, and 2008, a starting point of crisis in USA market, adopting the stakeholder approach. The sample is based on Fortune 500 where 100 companies are randomly selected. CSR performance is investigated using content analysis of annual non-financial reports. In total, twenty nine indicators are investigated for estimating CSR performance and are classified into five stakeholders' areas for estimating CSR performance namely: employee, consumer, government, supplier and society. The presence of information for each of the indicators in CSR reports is scored with 1 and the absence of relative information with 0 . Results show that companies decrease CSR projects because of a financial downturn. The decrease of CSR projects is greater in the USA than in Europe and other countries. However, there is no explanation why these stakeholders and indicators are selected in order to assess CSR performance and subjective evaluation procedure can be developed.

Njoroge (2009) examines how the current financial crisis affects multinational companies operating in Kenya and the effects of multinational companies in social projects and labor standards. Two approaches are adopted for the purpose of the study, a telephone interview survey and analysis of Covalence database. Results demonstrate that the economic downturn has no severe effect on labour standards while there is an adverse effect on funding and implementing social projects. Şchiopoiu Burlea et al. (2010) explore the influence of financial crisis and corruption on CSR in Romania. Both qualitative and quantitative methodological approaches are adopted based on HeRmeS project. Romanian organizations are affected by financial circumstances as the number of bankruptcies has been increased. The conclusion is that companies need to pay attention on the ethical part of their companies and on the institutional legitimacy of the manager's behavior. It is noted that there are difficulties in investigating the relationship of financial crisis, corruption and CSR as no consensus exists on the concept of CSR. The crucial question raised is whether companies will continue to implement CSR initiatives with the same intensity before and during the global financial crisis or will save financial capital to confront unexpected operation dilemmas. Arevalo and Aravind (2010) investigate the impact of financial crisis in CSR taking into account companies that adopt the principles of United Nations Global Compact (UNGC). In total, 271 USA members of UNGC have joined the study. It concluded that in some cases CSR is considered as a starting point for improving business operation. Companies that integrate UNGC principles with lesser conformity will be affected more by the financial downturn while companies that adopt a proactive policy concerning UNGC are affected less. Using the content analysis tool of CEO statements, six main CSR priorities are underlined in time of crisis: building strong leadership teams, applying innovation to solve the most complex global problems, forming partnerships with NGOs, maintaining core commitment to global citizenship, engaging in global dialogue on human rights and joining global discussions on climate change. 


\section{CSR performance tools}

The evaluation of CSR performance is a significant issue both for business and society (Carroll, 2000). Brilius (2010) states that discussion on CSR measurement has just begun. It is defined as “a business organization's configuration of principles of social responsibility, process of social responsiveness, and policies, programs, and observable outcomes as they relate to the firm's societal relationships" (Wood, 1991). Stainer (2006) defines the term of performance as "the organization's ability to achieve their objectives, not only in a resourceful manner but also consistently and sometimes, by losing sight of the purpose of analyzing it". By measuring CSR performance, companies can identify their strengths and weaknesses, modify their strategies and define opportunities for improvement (Kok et al., 2001; Sirgy, 2002). The development of valid and reliable indicators is an important factor of the measurement process (Carroll, 2000). Two main streams concern this type of indicators. The general one does not consider the direct and indirect effects of its sector in society (Graafland et al., 2003, 2004; Hino, 2001; Turker, 2009). The second stream recommends both general and sector-specific indicators (Azapagic, 2004; Azapagic and Perdan, 2000). However, there is no single approach to assess CSR performance and it is not always possible to determine CSR indices (Wolfe and Aupperle, 1999; Gjølberg, 2009).

Different methodological tools are provided in order to measure and assess CSR performance. Igalens and Gond (2005) state that there are five different methodologies for measuring CSR performance. The first one concerns the contents of annual publications where the measurement is subjective and can be easily modified. Another approach is referred to as pollution indexes that are not applicable to all types of industries. Perceptual measurements that depend on questionnaire' surveys are affected by administration preparation. Corporate reputation indicators and data produced by measurement organizations are the last two approaches where the halo effect play substantial role. Maignan and Ferrell (2000) distinguish three main categories: expert evaluations, single- and multiple-issue indicators and surveys of managers. The major limitation of expert evaluations and single indicators such as pollution index is that they represent only one dimension of the multiple aspects of CSR. As regards the third category of CSR performance it depends on the dedication of corporate managers on the commitment of CSR initiatives (Aupperle et al., 1985; Graafland et al, 2004, 2003), thus, the assessment of performance is not precise. Turker (2009) suggests four main methodological approaches in order to assess CSR performance: reputation indices and databases, single- and multiple -issue indicators, content analysis of corporate publications scales measuring CSR at the individual level, and scales measuring CSR at the organizational level. In relation to reputation indices and databases the ones included are Kinder, Lydenberg, and Domini Database, the Fortune Index, and the Canadian Social Investment Database. A significant restriction of single or multiple issues is that they concern a limited number of countries. The use of scales that measure the CSR perception of individuals is preferred to examine the socially responsible values of managers to socially responsible initiatives of organizations. Hino (2006), similarly, recommends measurement approaches namely, survey methodology, reputation index and rating, and content analysis of documents. Karaibrahimoglu (2010) evaluates CSR performance through the web pages of companies.

\section{Methodology}

\subsection{Global Reporting Initiative report}

The evaluation of CSR performance is based on companies that are certificated by CSR report standard. Whilst CSR reporting has not been standardized yet, a variety of reporting standards and frameworks have been developed such as GRI reporting framework, UNEP/SustainAbility (1997) and Deloitte Touche Tohmatsu International scorecard. Standards set the rules concerning what and how information should be published. CSR reporting informs society about the companies' ethical accountability to its stakeholders (Hassan and Harahap, 2010). Idowu and Papasolomou (2007) mention that five main reasons exist for CSR information: corporate reputation, stakeholder's pressure, economic performance, genuine concern and broad social/cultural reasons. Bebbington et al. (2008) note the increased trend for CSR reporting in developed economies. CSR communication and reporting has received attention in different countries such as Switzerland (Birth and Illia, 2008), Greece (Panayiotou et al., 2009), Finland (Tuominen et al., 2008), India (Raghu Raman, 2006) and New Zealand (van Staden and Hooks, 2007).

The GRI guidelines framework is considered the most complete framework concerning the CSR report. It is voluntary and presents reporting principles on an organization's economic, environmental, and social performance. The GRI Guidelines develop sector supplement in order to take into account the unique characteristics and challenges of 12 sectors: electric utilities, financial services, media, oil \& gas, apparel \& footwear, automotive, logistics \& transportation, telecommunications, food processing, construction \& real 
estate, public agency, event organizers, mining \& metals, NGO and airports. A GRI-based report includes five sections named vision and strategy, profile, governance structure, GRI content index and performance indicators which are distinguished in three dimensions of economy, environment and society. An important aspect of GRI guidelines is the application levels which provide information to the reader concerning the extent to which the GRI guidelines have been utilized. Three main levels are distinguished, named A, B and C which can be self-declared, third-party-checked and/or GRI-checked and each with the option of recognizing external assurance ("+"). In total, six reporting levels exist ranging from $\mathrm{C}$ to $\mathrm{A}+$.

\subsection{Research description}

The evaluation of CSR performance is based on companies that are certificated by GRI guidelines in order to ascertain whether their performance has changed. Karaibrahimoglu (2010) adopts a binary scale for assessing CSR reports using content analysis tool. However, this approach is essentially dichotomous (Haniffa and Cooke, 2005). Each country was affected by the financial crisis in different time periods and with different intensity (World Bank, 2009). The term of region market is adopted in order to specify the starting point of crisis homogenizing the differences in each country. Wyplosz (2010) states that the current financial crisis started at the same time both in Europe and the USA where the real starting point of financial crisis shows its effects in 2008 (Adamu, 2009, Decker and Sale, 2009). Thus, the application level of GRI guidelines is modified to a performance scale in order to evaluate the performance of companies before the financial crisis, 2007, and during the crisis, 2008, 2009 and 2010. A six point system score is created for CSR performance evaluation of each company for each year, Table 1. Totally, 112 companies are common during the investigated period in GRI report list (Note 1).

Table 1.

To test whether there is a significant difference of CSR performance a Wilcoxon signed rank sum test is conducted. It is widely used in CSR field in order to assess the difference of CSR projects between two samples (Haniffa and Cooke, 2005; Branco and Rodrigues, 2008) while Karaibrahimoglu (2010) elaborates the parametric paired-samples $t$ test. The test of the $H_{0}$ of the population median difference $M_{D}$ is zero (Aczel, 1993).

$\mathrm{H}_{0}: \operatorname{Median}_{\mathrm{A}}=\operatorname{Median}_{\mathrm{B}}$

$\mathrm{H}_{1}: \operatorname{Median}_{\mathrm{A}} \neq \operatorname{Median}_{\mathrm{B}}$

However, the assumption of the test is that the population distributions are symmetrical, in which case the mean and medians are identical. The hypothesis to be investigated is:

$\mathrm{H}_{0}$ : CSR performance is immutable in financial crisis period

$\mathrm{H}_{1}$ : CSR performance is significantly different in financial crisis period

\section{Results}

The sample in this study constitutes diverse sectors operating in different geographical regions. In total, there are 27 different sectors. The most important ones are: financial service (17\%), energy utilities (15\%), construction $(6 \%)$, conglomerates $(5 \%)$, technology hardware and telecommunications $(4,5 \%)$. With regards to the size, only 6 companies belong to small and medium size categories. In terms of market region, $65 \%$ of the sample have their headquarters in Europe, 27\% in America with 13,5\% in North America, 6,3\% in Asia and only 1\% in Oceanic region market. It is obvious that the behavior of European and American companies play an important role in the results as they consist more than $90 \%$ of the sample.

The Kolmogorov-Smirnov test is applied each year in order to ascertain whether the data are normally distributed or not. Results show that the data are not normally distributed, thus, the Wilcoxon signed rank sum test can be used. The outcome for each pair of CSR performance is illustrated in table 2. In the period between 2007, pre financial period, and 2008, the CSR performance seems to have increased as the null hypothesis is rejected at the level $\mathrm{a}=0.05$ ( $\mathrm{p}$-value $=0,000<0,05$ ) where $\mathrm{z}=-4,617$ and the mean of CSR performance of 2008 is bigger than 2007 with a smaller standard deviation $(1,86236<1,52244)$, Table 2 . It also provides the number of cases with a positive, negative difference and ties. However, Karaibrahimoglu (2010) concludes that companies decreased CSR projects for the period 2007-2008.

Table 2.

Table 3, illustrates the direction of CSR performance in financial downturn. For the period 2008-2009, the null hypothesis is rejected at the level $\mathrm{a}=0.05$ ( $\mathrm{p}$-value $=0,001<0,05$ ) with $\mathrm{z}=-3,284$ indicating that the CSR performance stills increases independently of the severe financial circumstances, Table 3 . 
Table 3.

As regards the period 2009-2010 there is not enough evidence to conclude statistically significant difference between CSR performance in 2010 and 2009 ( $\mathrm{p}$-value $=0,233>0,05$ ), Table 4. However, CSR performance in 2010 is greater than 2008 as $z=-3,409$ and $p$-value $=0,001<0,05$. The decrease of CSR performance in the last period is probably due to the fact that 2010 could be worse than the previous years because of Greek, Irish, Portuguese and Spanish financial downturns which can affect the global economy and, more particularly the North American one.

Table 4.

Companies that seriously take into account CSR, increase their performance even if the business environment does not support investments in CSR initiatives with the unique exception of the last period 2009 and 2010. During the last years, trust in businesses and capital markets has plummeted worldwide because of the collapse of global financial institutions such as Lehman Brothers. The social cohesion, structure and stakeholder expectations is constantly changing over time (Kitchin, 2002), especially in economic downturn. Companies, probably, increase their performance in order to gain not only the most common benefits that may arise from CSR implementation such as economic performance (Schiebel and Pochtrager, 2003) employee satisfaction (Fafaliou et al. 2006) and increased sales (Weber, 2008) but also the lost trust in businesses and capital markets (Decker and Sale, 2009). Trust between companies and stakeholders becomes more important than ever for business survival as the trust barometer index since 2007, pre financial period, declined dramatically until 2010 in most developed countries (Edelman Trust Barometer, 2010). It can be concluded that companies view CSR as a form of investment that helps to differentiate a company and redefine the trust between companies and society.

\section{Conclusions}

During the last decades, CSR has been dramatically increased, mostly in developed economies. The financial crisis has prompted companies to move away from the socially responsible behavior as it costs a lot to satisfy a stakeholder' expectations. The purpose of this study is to investigate the relationship between CSR performance and the financial crisis. Companies that are certificated by GRI reporting framework is selected modifying the application level in point score system. The results indicate increased CSR performance before and during the financial crisis except for the period 2009-2010. The benefits that may arise by the implementation of CSR strategy and initiatives are more important than ever before for the companies' survival. The investment view of CSR can help companies to differentiate their goods or services and re-establish the trust between companies and their stakeholders (Thomé, 2009). The financial crisis has raised the question whether CSR constitutes a threat for business survival because of the high cost of initiatives. Companies increase their CSR performance in order to build or sustain their brand name, consumers' trust and redefine the relationship between companies and society. Thus, the current crisis gives the opportunity to companies to redirect CSR from a threat to an opportunity. There are two limitations to this study, It is based only on companies that are common to listing in the four years of GRI listing, thus ignoring other companies; and secondly, it is based on large companies and so does not examine the behaviour of small and medium companies. Further research should study why CSR performance is increased in the period 2009-2010 and whether stakeholders' needs have changed in the financial downturn.

\section{References}

Aczel, A. (1993). Complete Business Statistics (2nd. ed.). Homewood, IL, Irwin.

Adamu, A. (2009). Effects of global financial crisis on Nigerian economy. International Journal of Investment and Finance, 1(1\&2), 11-21.

Aizenman, J., Chinna, M.D., \& Ito, H. (2010). The Financial Crisis, Rethinking of the Global Financial Architecture, and the Trilemma, ADBI Working Paper Series. [Online] Available: http://web.pdx.edu/ ito/ACI_adbi09162009.pdf (November 24, 2010).

Arevalo, J.A., \& Aravind, D. (2010). The impact of the crisis on corporate responsibility: the case of UN global compact participants in the USA. Corporate Governance, 10(4), 406-420.

Aupperle, K.E., Carroll, A.B., \& Hatfield, J.D. (1985). An Empirical Examination of the Relationship Between Corporate Social Responsibility and Profitability. Academy of Management Journal, 28(2), 46-463.

Azapagic, A. (2004). Developing a framework for sustainable development indicators for the mining and minerals industry. Journal of Cleaner Production, 12, 639-662 
Azapagic, A., \& Perdan, S. (2000). Indicators of sustainable development for industry: A General Framework, Institution of Chemical Engineers Trans IChemE, 78, Part B.

Bebbington, J., Larrinaga, C., \& Moneva, J.M. (2008). Corporate social reporting and reputation risk management. Accounting, Auditing \& Accountability Journal, 21, 337-361.

Birth, G., \& Illia, L. (2008). Communicating CSR: practices among Switzerland's top 300 companies. Corporate Communications: An International Journal, 13, 182-196.

Branco, M.C., \& Rodrigues, L.L. (2008). Factors Influencing Social Responsibility Disclosure by Portuguese Companies. Journal of Business Ethics, 83, 685-701.

Carroll, A.B. (2000). Commentary and an Overview of Key Questions on Corporate Social Performance Measurement. Business Society, 39(4), 466-478.

Commission of the European Communities. (2001). Green Paper- Promoting a European Framework for Corporate Social Responsibility, COM (2001) 366 final, Brussels.

Decker, S., \& Sale, C. (2009). An Analysis of Corporate Social Responsibility, Trust and Reputation in the Banking Profession, Part 1, 135-156, in Idowu, S. O. and Filho, W. L., Professionals' Perspectives of Corporate Social Responsibility, Springer-Verlag Berlin Heidelberg.

Deloitte Touche Tohmats International. (2001). Deloitte Reporting Sustainability Scorecard. [Online] Available: http://www.deloitte.com/view/en_GX/global/index.htm (October 1, 2010)

Edelman Trust Barometer. (2010). 2010 ANNUAL GLOBAL OPINION LEADERS STUDY. [Online] Available: http://www.edelman.com/trust/2010/docs/2010_Trust_Barometer_Executive_Summary.pdf (October 17, 2010)

European Commission. (2009). Economic Crisis in Europe: Causes, Consequences and Responses, EUROPEAN ECONOMY 7, Luxembourg.

Fafaliou, I., Lekakou, M., \& Theotokas, I. (2006). Is the European shipping industry aware of corporate social responsibility? The case of the Greek-owned short sea shipping companies. Marine Policy, 30, 412-419.

Fernández, B., \& Souto, F. (2009). Crisis and Corporate Social Responsibility: Threat or Opportunity?. International Journal of Economic Sciences and Applied Research, 2(1), 36-50.

Filardo, A., George, J., Loretan, M., Ma, G., Munro, A., Shim, I., Wooldridge, P., Yetman, J., \& Zhu, H. (2010). The international financial crisis: timeline, impact and policy responses in Asia and the Pacific, BIS Papers No 52. [Online] Available: http://www.bis.org/publ/bppdf/bispap52c.pdf (November 27, 2010).

Gjølberg, M. (2009). Measuring the immeasurable? Constructing an index of CSR practices and CSR performance in 20 countries. Scandinavian Journal of Management, 25(1), 10-22.

Global Reporting Initiative. [Online] Available: http://www.globalreporting.org/Home (October 1, 2010)

Graafland, J., Eijffinger, S.C.W., \& Smid, H. (2004) Benchmarking of Corporate Social Responsibility: Methodological Problems and Robustness. Journal of Business Ethics, 53(1-2), 137-152.

Graafland, J., Eijffinger, S.C.W., Stoffele, N.C.G.M., Smid, H., \& Coldeweijer, A.M. (2003). Corporate social responsibility of Dutch companies: Benchmarking and Transparency. [Online] Available: http://www.uvt.nl/faculteiten/fww/cmo (October 17, 2010).

Haniffa, R.M., \& Cooke, T.E. (2005). The impact of culture and governance on corporate social reporting. Journal of Accounting and Public Policy, 24, 391-430.

Hassan, A., \& Harahap, S.S. (2010). Exploring corporate social responsibility disclosure: the case of Islamic banks. International Journal of Islamic and Middle Eastern Finance and Management, 3(3), 203-227.

Hino, K. (2006). Corporate Social and Financial Performance: An Empirical Study on a Japanese Company. IFSAM VIIIth World Congress, September Berlin, Germany, 28-30.

Idowu, S.O., \& Papasolomoum, I. (2007). Are the corporate social responsibility matters based on good intentions or false pretences? An empirical study of the motivations behind the issuing of CSR reports by UK companies. Corporate Governance, 7(2), 136-147.

Igalens, J., \& Gond, J.P. (2005). Measuring Corporate Social Performance in France: A Critical and Empirical Analysis of ARESE data. Journal of Business Ethics, 56(2), 131-148. 
Karaibrahimoglu, Y.Z. (2010). Corporate social responsibility in times of financial Crisis. African Journal of Business Management, 4(4), 382-389.

Kitchin, T. (2002). Corporate social responsibility: a brand explanation. Brand Management, 10(4-5), 312-326.

Kok, P., van der Wiele, T., McKenna, R., \& Brown, A. (2001). A Corporate Social Responsibility Audit within a Quality Management Framework. Journal of Business Ethics, 31, 285-297.

Kytle, B., \& Ruggie, J.G. (2005). Corporate Social Responsibility as Risk Management: A Model for Multinationals, Corporate Social Responsibility Initiative, Working paper No. 10. Cambridge, MA: John F. Kennedy School of Government, Harvard University.

Lantos, G.P. (2001). The boundaries of strategic corporate social responsibility. Journal of Consumer Marketing, 18(2), 595-630.

Maignan, I., \& Ferrell, O.C. (2000). Measuring Corporate Citizenship in Two Countries: The Case of the United States and France. Journal of Business Ethics, 23(3), 283-297.

Maignan, I., Ferrell, O.C., \& Ferrell, L. (2005). A stakeholder model for implementing social responsibility in marketing. European Journal of Marketing, 39(9/10), 956-977.

Njoroge, J. (2009). Effects of the global financial crisis on corporate social responsibility in multinational companies in Kenya, Covalence Intern Analyst Papers. [Online] Available: www.covalence.ch/docs/Kenya-Crisis.pdf (October 30, 2010).

Orlitzky, M., Schmidt, F.L., \& Rynes, S.L. (2003). Corporate Social and Financial Performance: A Meta-analysis. Organization Studies, 24(3), 403-441.

Palazzi, M., \& Starcher, G. (2000). Corporate Social Responsibility and Business Success. Available at: http://www.ebbf.org (October 7, 2010).

Panayiotou, N.A., Aravossis, K.G., \& Moschou, P. (2009). Global Practices of Corporate Social Responsibility, Idowu, S.O. and Leal Filho, W., Springer Berlin Heidelberg.

Porter, M.E., \& Kramer, M.R. (2002). The Competitive Advantage of Corporate Philanthropy. Harvard Business Review (pp. 5-16).

Raghu Raman, S. (2006). Corporate Social Reporting in India-A View from the Top. Global Business Review, 7 , 313-324.

Schiebel, W., \& Pochtrager, S. (2003). Corporate ethics as a factor for success - the measurement instrument of the University of Agricultural Sciences (BOKU), Vienna. Supply Chain Management: An International Journal, 8(2), 116-121.

Şchiopoiu Burlea, A., Radu, C., Craciun, L., Ionascu, C., \& Lolescu, R. (2010). The relationship between financial crisis, corruption and Corporate Social Responsibility in Romania. Management \& Marketing, 8(1), $65-72$.

Sirgy, M.J. (2002). Measuring Corporate Performance by Building on the Stakeholders Model of Business Ethics. Journal of Business Ethics, 35, 143-162.

Stainer, L. (2006). Performance management and corporate social responsibility: the strategic connection. Strat. Change, 15, 253-264.

Taylor, J., \& Williams, J. (2009). A black swan in the money market. American Economic Journal: Macroeconomics, 1, 58-83.

Thomé, F. (2009). Corporate Responsibility in the Age of Irresponsibility: A symbiotic relationship between CSR and the financial crisis?. International Institute for Sustainable Development. [Online] Available: http://www.iisd.org/pdf/2009/csr_financial_crisis.pdf (October 3, 2010)

Tuominen, P., Uski, T., Jussila, I., \& Kotonen, U. (2008). Organization types and corporate social responsibility reporting in Finnish forest industry. Social Responsibility Journal, 4, 474-490.

Turker, D. (2009). Measuring Corporate Social Responsibility: A Scale Development Study. Journal of Business Ethics, 85, (4), 411-427.

UNEP/SustainAbility. (1997). Engaging stakeholders: The 1997 benchmark survey, United Nations Environment Program and SustainAbility, Ltd., London, 39 pp. 
van Staden, C.J., \& Hooks, J. (2007). A comprehensive comparison of corporate environmental reporting and responsiveness. The British Accounting Review, 39, 197-210.

Weber, M. (2008). The business case for corporate social responsibility: A company-level measurement approach for CSR. European Management Journal, 26(4), 247-261.

Wim, N. (2009). The Financial Crisis of 2008 and the Developing Countries. Discussion Paper No. 2009/01. UNU-WIDER. The World Institute for Development Economics Research. United Nations University. Helsinki. Finland.

Wolfe, R., \& Aupperle, K. (1991). Introduction to Corporate Social Performance: Methods for Evaluating an Elusive Construct. In J. E. Post (ed), Research in Corporate Social Performance and Policy, 12 JAI Press, Greenwich, CT, (pp. 265-268).

Wood, D.J. (1991). Corporate social performance revisited. Academy of Management Review, 16(4), 691-718.

World Bank. (2009). Turmoil at Twenty - Recession, Recovery, and Reform in Central and Eastern Europe and the Former Soviet Union, World Bank, Washington D.C.

Wyplosz, C. (2010). The Eurozone in the Current Crisis, ADBI Working Paper Series, Asian Development Bank Institute. [Online] Available: http://www.adbi.org/files/2010.03.26.wp207.eurozone.current.crisis.pdf (November 24, 2010).

Note

Note 1. GRIReportsList , available at: http://www.globalreporting.org/ReportServices/GRIReportsList/

Table 1. A six point system score

Source: Authors (2010)

\begin{tabular}{|c|c|}
\hline Application level & Point system score \\
\hline C & 1 \\
\hline C + & 2 \\
\hline B & 3 \\
\hline B + & 4 \\
\hline A & 5 \\
\hline A + & 6 \\
\hline
\end{tabular}

Table 2. CSR performance during financial crisis 2007-2008

\begin{tabular}{|c|l|c|c|c|c|c|}
\hline $\begin{array}{c}\text { CSR } \\
\text { performance }\end{array}$ & & $\mathrm{N}$ & Mean & $\begin{array}{c}\text { Std. } \\
\text { Deviation }\end{array}$ & $\mathrm{Z}$ & $\begin{array}{c}\text { Asymp. Sig. } \\
\text { (2-tailed) }\end{array}$ \\
\hline 2007 & $\begin{array}{l}\text { Negative } \\
\text { Ranks }\end{array}$ & $5^{\mathrm{a}}$ & 4,1339 & 1,86236 & \multirow{2}{*}{, 000} \\
\hline 2008 & $\begin{array}{l}\text { Positive } \\
\text { Ranks }\end{array}$ & $31^{\mathrm{b}}$ & 4,7054 & 1,52244 & $-4,617$ & \multirow{2}{*}{} \\
\hline & Ties & $76^{\mathrm{c}}$ & & & & \\
\hline & Total & 112 & & & & \\
\hline
\end{tabular}

a. CSR2008 < CSR2007, b. CSR2008 > CSR2007, c. CSR2008 = CSR2007

Source: Authors (2010) 
Table 3. CSR performance during financial crisis 2008-2009

\begin{tabular}{|c|l|c|c|c|c|c|}
\hline $\begin{array}{c}\text { CSR } \\
\text { performance }\end{array}$ & $\mathrm{N}$ & Mean & $\begin{array}{c}\text { Std. } \\
\text { Deviation }\end{array}$ & $\mathrm{Z}$ & $\begin{array}{c}\text { Asymp. Sig. } \\
\text { (2-tailed) }\end{array}$ \\
\hline 2008 & $\begin{array}{l}\text { Negative } \\
\text { Ranks }\end{array}$ & $5^{\mathrm{a}}$ & 4,7054 & 1,52244 & & \multirow{2}{*}{, 001} \\
\hline 2009 & $\begin{array}{l}\text { Positive } \\
\text { Ranks }\end{array}$ & $25^{\mathrm{b}}$ & 5,0268 & 1,35872 & & \\
\hline & Ties & $82^{\mathrm{c}}$ & & & & \\
\hline & Total & 112 & & & & \\
\hline
\end{tabular}

a. CSR2009 < CSR2008, b. CSR2009 > CSR2008, c. CSR2009 = CSR2008

Source: Authors (2010)

Table 4. CSR performance during financial crisis 2009-2010

\begin{tabular}{|c|l|c|c|c|c|c|}
\hline $\begin{array}{c}\text { CSR } \\
\text { performance }\end{array}$ & N & Mean & $\begin{array}{c}\text { Std. } \\
\text { Deviation }\end{array}$ & Z & $\begin{array}{c}\text { Asymp. Sig. } \\
\text { (2-tailed) }\end{array}$ \\
\hline 2009 & $\begin{array}{l}\text { Negative } \\
\text { Ranks }\end{array}$ & 4 & 5,0268 & 1,35872 & & \multirow{2}{*}{,233 } \\
\hline 2010 & $\begin{array}{l}\text { Positive } \\
\text { Ranks }\end{array}$ & 10 & 5,0714 & 1,36701 & & \\
\hline & Ties & 98 & & & & \\
\hline & Total & 112 & & & & \\
\hline
\end{tabular}

a. CSR2010 < CSR2009, b. CSR2010 > CSR2009, c. CSR2010 = CSR2009

Source: Authors (2010) 